\title{
Early years teachers and digital literacies: Navigating a kaleidoscope of discourses
}

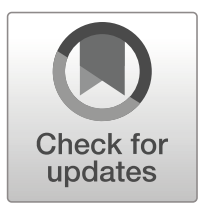

\author{
Karen Daniels ${ }^{1}$ (D) $\cdot \operatorname{Kim}_{\text {Bower }}{ }^{1} \cdot$ Cathy Burnett $^{1} \cdot$ Hugh Escott $^{1} \cdot$ \\ Amanda Hatton $^{1} \cdot$ Ester Ehiyazaryan-White ${ }^{1} \cdot$ Jemma Monkhouse $^{1}$
}

Received: 23 July 2019 / Accepted: 23 October 2019 / Published online: 10 December 2019

(C) The Author(s) 2019

\begin{abstract}
For many young children in developed countries, family and community life is mediated by digital technology. Despite this, for early years educators, the process of integrating digital technologies into classroom practice raises a number of issues and tensions. In an attempt to gain insights from early years teachers, we draw from semistructured interview data from ten practising teachers which explored their perspectives on digital technologies within their personal and professional lives, and of children's use of digital technologies within and outside educational settings. Our analysis builds on previous work that suggests that teachers draw on multiple discourses related to conceptualisations of childhood when thinking about digital technology and young children. In this paper we contribute to these discussions, drawing specifically on examples from the data where teachers articulate their understandings of children's use of digital technology where this relates directly to children's literacy practices. We assert that narrow conceptualized notions of literacy, compounded by national imperatives to raise print literacy standards, add another layer of discursive complexity that comes to the fore when teachers are asked to provide a rationale for the promotion of digital literacies in early years classrooms. A broader framing of literacy therefore, is needed if the potential of digital technologies in the early years is to be realized.
\end{abstract}

Keywords Digital literacy - Early years education · Early years teachers · Discourse - Digital practices

\section{Introduction: Young children's engagement with the digital}

For many young children in developed countries digital media are now an integral part of family life. Regular surveys of media use suggest that digital devices are ever more

Karen Daniels

K.Daniels@shu.ac.uk

Extended author information available on the last page of the article 
ubiquitous, utilised for play, communication and entertainment (Ofcom 2014, 2016, 2019), and qualitative studies of digital media in the home have mapped how children use them in purposeful, interest-driven activity (e.g. Davidson et al. 2017; Murphy and Headley 2019; Plowman 2015). In many ways these young children's communicative practices reflect the digital practices they encounter in the world around them: practices that are multimodal, mobile and that move between multiple media. Importantly not all children have equal access to digital technologies, and practices vary across homes (Stephen et al. 2013). For example, while children in less affluent homes may have access to tablets, these may be of inferior quality, and families may rely on free apps which are dense with advertising and lacking the creative potential on offer through paid content (Marsh et al. 2015). Moreover, concerns about the (in)appropriateness of digital technologies for young children are widespread, linked to issues of safeguarding, and the health effects of screen-time on eyesight, posture, sleep and so on, as well as anxieties about displacement - about what children might be doing if they were not spending so much time with screens (Academy of Pediatrics Committee on Education 2010; Cordes and Miller 2000; Wood et al. 2013). While the picture is mixed, a number of studies have challenged these concerns, demonstrating: that young children's digital practices are often highly social, and indeed that applications such as Skype can provide valuable opportunities for young children to engage with relatives in a time when families are increasingly dispersed (Gillen et al. 2018; Davidson 2009); that children often blend off and on screen play (Harrison and McTavish 2018); and that some young children are operating not just as consumers but as creators and producers of digital content (Marsh et al. 2015; Ofcom 2019).

This complex context has particular implications for considering how literacy provision is framed in early years settings. For two decades literacy scholars have argued that literacy provision in education should reflect the digital practices that pattern everyday life (e.g. Snyder 2001; Cope and Kalantzis 2000). Specifically arguments have intensified for provision for 'digital literacies.' It is recognised that 'digital literacy' is a rather ambiguous term, which has been used - among other thingsto refer to general technological competence or to specific literacy skills linked to information retrieval and evaluation. Instead, we use the term to refer to those practices associated with digital media, often characterised by mobility, connectivity, multimodality and multiple media (Burnett and Merchant 2018). Our use of the term plural 'literacies' is an essential point here, as this reflects our conviction that literacies are multiple and situated in local sites. In some countries considerable progress has been made in integrating digital literacies within the curriculum (see for example Kumpulainen and Sefton-Green 2019). However, in others progress is slow. Indeed in England, where we are based, literacy as defined in curriculum documentation is limited to the acquisition of a set of discrete skills associated with print and there is no reference to screen-based text at all, let alone the diverse range of media we might associated with digital literacies (see DFE 2013, 2017).

\section{Early years teachers and digital literacy}

Against this background, early years professionals must steer a course between ensuring young children build on their 'digital capital' (Bearne 2009) to benefit from the 
creative and communicative possibilities of the digital age, and reassuring parents and carers that provision is not undermining children's social, physical or psychological wellbeing (Kontovourki et al. 2017). In some countries, including England, this may well involve supplementing adherence to national, regional and/or local policy requirements with an ambition to enrich and expand literacy provision in ways that reflect digital literacies even when this is not a requirement. Such sensitive work would seem to require an orientation to digital media use that is confident, critical and creative. However, it is possible that early years teachers are not well supported to fulfil this role as professional development and models of practice in this area are sparse (Marsh et al. 2017). There is therefore a need to know more about how early years professionals are navigating these competing imperatives, and about the beliefs, values and assumptions that inform this aspect of their work.

Various studies of teachers of the $0-11$ age group have noted that teachers feel reluctant or ill-equipped to promote digital literacies in educational settings. Paradoxically this has been observed to be the case both by those wedded to teacher-led pedagogies (Ihmeideh 2009; McDougall 2010), and by those committed to the play-based and child-centred approaches associated with early years practice (Lynch and Redpath 2014). Technology mediated literacies have been variously seen by teachers as too open-ended and not openended enough, as different sets of assumptions intersect with societal and institutional discourses about the value (or indeed the detriment) of digital technologies (Honan 2008). This situation may be exacerbated when considering digitally mediated practices in relation to literacy provision, not least because, despite some exceptions, measures of literacy standards tend to omit digital media (not least because of difficulties in measuring achievements in this area). Even those keen to integrate digital media in empowering and open-ended ways may well feel constrained from doing so due to institutional pressures to prioritise print literacy (Lynch and Redpath 2014).

If, as is the case, professional development in this area is sparse, then it might be expected that teachers would look to their personal experience of digital media when planning classroom activity. Again, however, the picture is mixed. It is certainly the case that it is inappropriate to assume that all twenty-first century teachers will bring rich experience of digital media with them to the classroom (Robinson and Mackey 2006). Teachers' experiences vary both in quantity and range, and different kinds of experience might be associated with different kinds of pedagogy. Graham (2008), for example, found that those with a 'playful social' 'orientation to technology in their own lives (e.g. those who enjoyed gaming) tended to approach literacy pedagogy with a similar orientation, planning more creative, open-ended and collaborative text-making activities for learners. However such correlations may not always play out in practice. As one of us has explored previously in an analysis of pre-service teachers' perspectives on digital literacy in their personal and professional lives, even those proficient in using technology in multiple ways may not transfer their confidence to the classroom, possibly because they do not see the relevance of their personal digital experience to curriculum and pedagogy. Decisions can be 'framed by a fluctuating sense of appropriateness, legitimacy and risk' as personal and professional identities intersect (Burnett, 2011: 433). Such research suggests that teachers' digital skills, orientations and attitudes are not fixed but contingent on certain kinds of experiences and contexts.

Changes in communication and literacy practices may well impact on individuals' confident articulation of the place, value and role of digitally mediated literacy practices 
in the classroom. While a decade ago many teachers may have entered the classroom lacking the confidence to experiment with technology (Graham 2008; Honan 2008; Author 3 2011), we might expect a newer generation of teachers to share a greater degree of enthusiasm and agency. While teachers have always had to navigate multiple discourses in their professional practice, such contradictions may intensify when considering digital literacy in the early years, as the qualities and dispositions associated with digital media may be seen to undermine those associated with early schooling. The group of Swedish teachers that Hernwall (2016) worked with, for example, suggested that the integration of digital media threatened the safe, closed environment they felt was essential to early schooling. While early childhood educators may be more confident in their personal use of digital technologies (and therefore digitally mediated communication) than previous generations of teachers, they may be less confident in their use within early years settings (Hatzigianni and Kalaitzidis 2018). Such studies suggest not so much that teachers are out of touch, but uncertain about how best to align practices mediated by digital technology with existing values and practices associated with early childhood education. Moreover, in England, recent times have been characterised by rapid educational reform in the areas of inspection, teacher education and curriculum, developments that may well have focused attention sharply on print literacy competencies.

Against this complex background, this study aimed to generate insights into teachers' perceptions of digital literacies in their lives, in their professional role, and in the lives of the children they taught. It aimed to investigate the personal, societal, institutional or other factors that were influencing, supporting or limiting the integration of digital literacies within their classrooms.

\section{The study}

The study was part of a larger European study (Kontovourki and Tafa, 2019) that took place as part of the work of an EU Cost Action funded network, The digital literacy and multimodal practices of young children (DigiLitEY funded by the European Cooperation in Science and Technology), which aimed to advance understandings of young children's digital literacy practices (see http://digilitey.eu/). In the strand of the project reported here, a team of eight interviewers collected data from ten participants in England using semi-structured interviews over a period of 6 months in 2017. The purposive sample was selected from practising teachers identified through the research team's personal and professional networks; eight women and two men whose teaching experience ranged from six to thirty-six years. At the time of data collection the teachers were working with children aged two to eight years old in a range of settings: an Early Years centre, a private nursery and 8 primary schools. The study utilised an interview schedule devised as part of the wider European project. This addressed: participants' own use of digital literacies in everyday life, their views on children's use, and the ways in which these were used in their classrooms. Interview questions were organised under the following headings: teachers' perceptions and own use of digital literacies outside educational settings; teachers' perceptions and use of digital literacies in educational settings; and connections with broader conceptualisations of teachers' role and 
professional practice/identity. The study was given ethical approval by the Sheffield Hallam University Research Ethics Committee.

Interviews were recorded, transcribed and reviewed by participants prior to analysis. Analysis was approached thematically, with NVivo qualitative data analysis software used to record inductive codes and to identify emerging themes and patterns in the data. In order to maximise inter-rater reliability, the process began with a period of collaborative coding by the whole team, during which selected interviews were discussed and coded. This was followed by coding of remaining transcripts by pairs of researchers. Codes were then reviewed by the whole team, and collapsed or expanded as appropriate. The transcripts were then revisited for a final time with particular reference to emerging themes.

\subsection{Analysis and findings: The task of the early years teachers and the tensions between digital technology and traditional literacy}

The work of teachers is situated within a socio-historical matrix (Gee et al. 1992) and their cultural, political, economic, political and social positions and experiences may shape the ways in which they talk about and make sense of their work in the classroom. As teachers described their experiences and talked about their aims and practices, they drew on a number of interrelated discourses.

In what Selwyn (2003) terms the information age, the discursive construction of childhood intersects with understandings of digital technology. According to Selwyn (2003), in such discourses, the child may be positioned as naturally competent, dangerous, victimized, or needy, portrayals that have permeated debates for over 20 years (Selwyn 2003). Like Selwyn (2003) and Mertala (2019) we noted that our teachers drew on similar discourses when asked about their pupils' use of digital technologies at home and in school. Our teachers were both alarmed and intrigued by the skill and confidence of some children. Simultaneously, they were concerned about what might be age appropriate 'play' activity for young children. These concerns intersected with national imperatives around safeguarding, e-safety, health and obesity. In addition, and as we were interested in the ways in which technologies mediate literacy practices, we were particularly cognisant of the way in which England's current educational climate, with its emphasis on print literacy standards, appeared to add another layer of complexity for our teachers. This drew our focus towards the ways in which power structures, such as policy and testing arrangements, created a more demanding challenge for our teachers. This additional layer suggests that the conceptualisation of literacy in the statutory curriculum further amplified teachers' difficulties in rationalising the use of digital technologies to enhance children's digital literacy practices in early years classrooms. However, despite their concerns over children's print literacy skills our teachers also questioned the long-term value of print literacy skills, with an eye on the future literate adult, and the competencies they may need for adult life. Jason commented:

We had a big debate. There is nowhere in the curriculum yet that suggests an opportunity to write a formal email, but yes we still all write formal letters. It is a nice thing to do, a handwritten letter, but we teach the children where to put the address and here to put the contact details and every child will leave the junior school knowing how to write a formal letter by hand.... I have never handwritten 
a letter but I write several emails a day. So- I don't know, are we giving them the right skills?

In our analysis, we also noted how teachers' comments often mentioned the device associated with digital technology, such as the camera, iPad, or computer. Digital technology then was often positioned as a 'thing' or 'object'. Often, digital technology was presented as a 'tool' to help pupils meet pre-determined print literacy goals. At other times it was seen as in opposition to those goals. Only rarely did our early years teachers refer to digital technology in ways that moved away from seeing it as more than a 'resource', and referring to its mobility and potential for generating and enhancing young children's communicative practices.

When teachers brought together the topics of digital technology and early literacy pedagogy, they tended to do so in one or more of the following ways:

a) positioning digital technology as a pedagogical tool or resource to be utilised in service of existing print literacy goals;

b) positioning digital technology use as activity that stands in opposition to print literacy goals;

c) emphasising the pedagogical goal of 'balancing' digital practices and print literacy competencies.

\subsection{Digital technology as a pedagogical tool to be utilised in service of existing print literacy goals}

This section considers instances where teachers discussed the ways in which they saw digital technology as a way of supporting their delivery of the curriculum and pedagogical goals for print literacy, particularly with reference to those children who found print literacy challenging some way.

Emilie described how phonic iPad apps can reinforce early phonics instruction:

We use it a lot- I've got one here. We use it a lot for phonics because it helps, you know, when the children are trying to do a phonics activity.... There's hairy phonics that the children have been on that just helps to re-inforce their letter sounds.

Carly identified children with special educational needs and disabilities (SEND) as a group who could potentially benefit from the affordances of digital literacies most. She described her observations of a child with autism for whom it was helpful to use a keyboard as he found it difficult to manipulate a pencil. Emilie commented that digitally mediated literacies can help children with dyspraxia, hypermobility or those who struggle with fine motor skills to write by using a keyboard, as they did not have to resort to handwriting. In a similar account of affordances of the digital, Hannah described a child who is imaginative ('has great ideas') and verbally proficient, but who struggles to write. For this child, voice recording ideas and thoughts provided an opportunity to participate. Karine meanwhile reflected on technology as a tool that could support higher achievers or support lower achievers that are struggling to write for example. It can record what they're saying and convert it into sentences.' 
Some participants also stated that they felt technology benefitted children who they judged to struggle with reading. Carly, for example, described six-year-old children in her class who found interactive books more accessible as they provide additional clues while reading. She also described how one girl liked reading from an iPad because it was not possible for other children to identify her as having 'lower ability' in reading as 'no one could see it was a pink book when she had the iPad out'. Print literacy when mediated by digital technology was seen as more appealing to children's interest and therefore motivating. For example, Hannah described how the affordances of digital technology allowed her to be more flexible in her lesson delivery whilst providing children with the opportunity to participate; she noted how children 'seem to be more willing to write if it is digital'.

\subsection{Digital technology as activity that stands in opposition to print literacy goals}

At other times, teachers' ideas about appropriate experiences played out in their reflections on the kinds of activities that could be considered as early literacy, and the potential negative impact on print literacy skills. Emilie stated:

I think that from a very young age the children are exposed to, particularly mobile phones and tablets and iPads, a lot of the children either have their own or they've got one at home, like a family one. They play a lot of computer games as well and its really big part of their life. They spend a lot more time with technology and I think it has-it seems to have affected the motor skills and things because they're all really confident on iPads and tablets, but in terms of writing, they're not as confident as we'd expected.

Likewise, Josie, stated that 'these advancements in technology are perhaps detracting from children's basic skills' and Emilie raised concerns about how engagement with digital technologies might impact on established and traditional understandings of social, language and literacy development:

I've got children who are 22-36 months developmentally who can use an iPad, yet can't recognise their name or hold a pencil and a lot of the time I find that I do all the speech and language.[...]I see children who have no social interaction, they have not been spoken to.

In the following example Katy describes a child as responding passively to the multimodal affordances offered by multimodal texts (perhaps becoming lazy in the process), seeing this response as at odds with traditional print literacies:

Sometimes it can help support the children because if it's digital then they press the button and it makes a sound. Whether that means that it reads it to them or whether that means that it's-rather than just looking at a picture you've got the sound of an animal, so it's more interactive. [...] So it's more interactive than just printed text. But then I also don't want becoming over-reliant on always thinking that they can press a button and then it will do it for them. 
The examples above summarise a prevalent concern by most of the participants; the use of digital technology meant that children's print literacy skills and proficiency in oral language were suffering.

\subsection{The pedagogical goal of balancing digital practices and print literacy competencies}

Often, the school curriculum was seen as providing a 'balance' between children's home experiences (perceived as mostly digitally mediated) and school experiences (print literacies). Children's engagement with digital technologies in the home often raised concern and was seen as counter to teachers' curricular aims sometimes standing in the way of established trajectories of developmental learning. In an attempt to reconcile the resulting tensions, teachers often presented a notion of 'balance'. Here is an example extract from Karine's interview:

So story time is always protected. It doesn't matter what happens within that day, story time occurs. It might be an audio book, it might be a real book that we use, it might be one of the bed time stories from CBeebies, or a story online, or it might just be us sat with a puppet retelling a story, and I think it's important that they have a mixture on it. The children do like the fact that when they go home, whereas some of our kids won't have any access to stories, now they know that they can go on to CBeebies and find some stories that they can listen to.

In a similar way, Emilie reconciled the dissonance between print literacies and digital literacies, referring to each separately:

They need both, they need to be able to see the value in both of them and not just think that having a phone is the be all and end all, but actually take price in the fact that you can write your name and you can write a sentence, you can have a go at writing letters and sounds, because that is still using text. Get a stick. Go and write it out in the mud, but just making sure that actually they have those experiences.

Ultimately, Emilie justifies digital literacy with a reference to print texts, and then drawing on a discourse of childhood, contrasts this with a child playing, presumably outdoors, making marks (an early literacy writing goal) in the mud. The notion of 'balance' is an interesting concept as it is representative of teachers' beliefs that print literacy competencies and digital practices are very different things, rather than collectively constituting a broad range of children's literacy practices.

\section{Discussion}

Our participants' responses reflected a number of current debates that they have to negotiate, and which may raise contradictions for them in terms of how they articulate the place of digital technology in the classroom, These competing perspectives, we believe, are compounded by the current emphasis on print 
literacy standards in England, making it difficult for teachers to articulate any coherent rationale for the integration of digital literacy in early education settings in the current social, political and educational climate. Stable notions of language and literacy were also at work as teachers attempted to reconcile both the digital and more traditional conceptualisations of literacy. Where literacy is fixed within a statutory curriculum, it clearly differs from the more fluid articulation of the integration of technologies in the everyday lives of teachers and their pupils. The conceptualisation of literacy as stable is inherent in school life, which means teachers are simultaneously working within models of language and literacy that do not necessarily reflect the language and literacy practices in which they and their pupils engage outside of school contexts (Agha 2003: 232).

As we analysed our transcripts, we noted one teachers' comments that appeared to explore the potential of digital technology as seen as integral to young children's meaning making practices. Julie noticed the following:

So they will free-flow. You will quite often find them - the other day they got the Bee-Bots, they went to the craft area and thy were making super hero jackets for then, and then they made chariots because Spiderman was hugging hulk along and that is what I love about my job, the fact that they were finding new ways to use technology. I had a little boy who decided that he was going to go on the CBeebies app and was quite happy navigating trying to teach himself how to speak Spanish using either Dora the Explorer or somebody, and I love that, that's how they use it.

This extract refers to the fluidity of children's meaning making practices, giving rise to digital literacy practices as they investigate and explore technology around them. Julie was an exception, and other participants found it more difficult to articulate a vision for what digitally mediated literacy practices might look like in an early years classroom.

\section{Conclusion and recommendations}

The integration of digital literacies in early years classrooms may be variously intensified or undermined as it comes into dialogue with other developments and priorities. Teachers' pedagogical work is negotiated within a shifting framework of societal, technological and curricular change, and the nature of this work is complicated further by teacher's personal understandings, values and beliefs and the ways that these interplay with institutional goals and demands (Pillen et al. 2013). The findings of this study contribute to research that has explored the multifarious and often conflicting discourses that come into play as early years teachers articulate the role of digital technologies in early education. Our interest in particular, was the way in which teachers articulated the relationship between digital technology and understandings of early literacy. We suggest that narrow conceptualisations of literacy, presenting literacy as fixed, print-based and as a set of skills to be acquired, mean that many teachers are unable to articulate a clear rationale for the inclusion of digital technologies in the early years classroom in any open-ended way, without reference to existing print literacy goals. This gives rise to the three categories 
identified above; digital technology in service of pre-existing literacy goals; digital technology in opposition to pre-existing literacy goals; and the pedagogical role of balancing children's digital and print experiences. In these examples, digital technology is mainly referred to in terms of a 'classroom resource' to enhance such goals. It is clear that in an era characterised by significant communicative change, national imperatives such as the raising of perceived low literacy standards, and print-based notions of literacy stand in opposition to the generation of new understandings of the potential of early literacy learning mediated by digital technology.

As noted by Mertala (2019), the origins of teachers' beliefs about digital technologies in the early years and the ways that these can be changed, are significant areas for development and exploration. Our teachers indeed appeared to find it difficult to offer a clear position without drawing on prevalent dominant discourses of childhood (Selwyn 2003). Where early literacy practices were concerned, this added another layer of complexity. What appears to be needed are new ways of understanding the potentiality of children's engagement in digital literacy practices, which demands not only looking in open-ended and exploratory ways at young children's digitally mediated activity, but also challenging conceptualisations of literacy that reduce it to a set of print literacy skills.

Open Access This article is licensed under a Creative Commons Attribution 4.0 International License, which permits use, sharing, adaptation, distribution and reproduction in any medium or format, as long as you give appropriate credit to the original author(s) and the source, provide a link to the Creative Commons licence, and indicate if changes were made. The images or other third party material in this article are included in the article's Creative Commons licence, unless indicated otherwise in a credit line to the material. If material is not included in the article's Creative Commons licence and your intended use is not permitted by statutory regulation or exceeds the permitted use, you will need to obtain permission directly from the copyright holder. To view a copy of this licence, visit http://creativecommons.org/licenses/by/4.0/.

\section{References}

Agha, A. (2003). The social life of cultural value. Language and Communication, 23, 231-227.

American Academy of Pediatrics Committee on Public Education. (2010). Media education. Pediatrics, 104, 1012-1017.

Bearne, E. (2009). Multimodality, literacy and texts: Developing a discourse. Journal of Early Childhood Literacy, 9(2), 156-187.

Burnett, C. (2011). Shifting and multiple spaces in classrooms: an argument for investigating leraners' bondary-making around digital networked texts. Journal of Literacy and Technology, 12(3), 2-23.

Burnett, C. \& Merchant, G. (2018). New media in the classroom: rethinking primary literacy. London: Sage.

Cope, B., \& Kalantzis, M. (Eds.). (2000). Multiliteracies; Literacy, learning and the design of social futures. London: Routledge.

Cordes, C., \& Miller, E. (2000). Fool's gold: A critical look at computers in childhood. College Park: Alliance for Childhood.

Davidson, C. (2009). Young children's engagement with digital texts and literacies in the home: pressing matters for the teaching of English in the early years of schooling. English Teaching: Practice and Critique, 8(3), 36-54.

Davidson, C., Danby, S., \& Thorpe, K. (2017). "Uh oh": Producing multimodal meaning making during viewing of YouTube videos in preschool. In M. Narey (Ed.), Multimodal perspectives of language, literacy and learning in early childhood: The creative and critical "art" of making meaning. Educating the young child (2nd ed., pp. 233-255). New York: Springer. 
Department for Education (DFE) (2013). The National Curriculum in England: primary curriculum. https:/www.gov.uk/government/publications/national-curriculum-in-england-primary-curriculum. Accessed 2 Apr 2019.

Department for Education (DFE) (2017). Statutory Framework for the Early Years Foundation Stage. https:/www.foundationyears.org.uk/files/2017/03/EYFS_STATUTORY_FRAMEWORK_2017.pdf. Accessed 2 Apr 2019.

Gee, J. P., Michaels, A., \& O'Connor, M. C. (1992). Discourse analysis. In M. D. Le Compte, W. L. Millroy, \& J. Preisslle (Eds.), The handbook of qualitative research in education (pp. 227-291). San Diego: Academic Press.

Gillen, J. Matsumoto, M., Aliagas, C., Bar-lev, Y., Clark, A., Flewitt, R.S., Jorge, A., Kumpulainen, K., Marsh, J., Morgada, M., Pacheco, R., Poveda, D., Sairanen, H., Sandberg, H., Scott, F., Sjöberg, U., Sundin, E., Tigane, I., \& Tomé, V. (2018). A day in the digital lives of children aged 0-3. http://digilitey. eu/wp-content/uploads/2019/03/0-to-3s-FINAL-Report-v3.pdf. Accessed 2 Apr 2019.

Graham, L. (2008). Teachers are digikids too: the digital histories and digital lives of young teachers in English primary schools. Literacy, 42(1), 10-18.

Harrison, E., \& McTavish, M. (2018). 'i'Babies: Infants' and toddlers' emergent language and literacy in a digital culture of iDevices. Journal of Early Childhood Literacy, 18(2), 163-188.

Hatzigianni, M., \& Kalaitzidis, I. (2018). Early childhood educators' attitudes and beliefs around the use of touchscreen technologies by children under three years of age. British Journal of Educational Technology, 49(5), 883-895.

Hernwall, P. (2016). 'We have to be professional' - Swedish preschool teachers' conceptualisation of digital media. Nordic Journal of Digital Literacy, 10(1), 5-23.

Honan, E. (2008). Barriers to teachers using digital texts in literacy classrooms. Literacy, 42(1), 36-43.

Ihmeideh, F. M. (2009). Barriers to the use of technology in Jordanian pre-school settings. Technology, Pedagogy and Education, 18(3), 325-341.

Kontovourki, S., Garoufallou, E., Ivarsson, L., Klein, M., Korkeamaki, R. L., Koutsomiha, D., MarciBoehncke, G., Tafa, E., \& Virkus, S. (2017). Digital literacy in the early years: Practices in formal settings, teacher education, and the role of informal learning spaces: A review of the literature. http://digilitey.eu/working-groups/wg2-digital-literacy-in-early-years-settings-schools-and-informallearning-spaces/. Accessed 2 Apr 2019.

Kontovourki, S., \& Tafa, E. (Eds.). (2019). Early years' and primary teachers' digital literacies in personal lives and professional practice: A cross country report. DigiLitEY: WG2 Digital Literacy in Early Years Settings, Schools, and Informal Learning Spaces.

Kumpulainen, K., \& Sefton-Green, J. (Eds.). (2019). Multiliteracies and early years innovation: Perspectives from Finland and beyond. Abingden: Routledge.

Lynch, J., \& Redpath, T. (2014). 'Smart' technologies in the early years literacy education: a meta-narrative of paradigmatic tensions in iPad use in an Australian preparatory classroom. Journal of Early Childhood Literacy, 14(2), 147-174.

Marsh, J., Plowman, L., Yamada-Rice, D., Bishop, J. C., Lahmar, J., Scott, F., \& Winter, P. (2015). Exploring play and creativity in pre-schoolers' use of Apps: Final project report. http://www.techandplay. org/reports/TAP_Final_Report.pdf. Accessed 2 Apr 2019.

Marsh, J., Kontovourki, S. Tafa, E. and Salomaa, S. (2017). Developing digital literacy in early years settings: Professional development needs for practitioners. A White Paper for COST Action IS1410. http://digilitey. eu/wp-content/uploads/2017/01/WG2-LR-jan-2017.pdf. Accessed 2 Apr 2019.

McDougall, J. (2010). A crisis of professional identity: how primary teachers are coming to terms with changing views of literacy. Teaching and Teacher Education, 26, 679-687.

Mertala, P. (2019). Wonder children and victimizing parents- preservice early childhood teachers' eliefs about children and technology at home. Early Child Development and Care, 189(3), 392-404.

Murphy, S., \& Headley, M. (2019). The role of digital literacy in teen mothers' and their children's literacy. Journal of Early Childhood Literacy. Online first.

Ofcom (2014). Children and Parents: media use and Attitudes Report. http://stakeholders.ofcom.org. uk/binaries/research/media-literacy/media-use-attitudes-14/Childrens_2014_Report.pdf . Accessed 2 Apr 2019.

Ofcom (2016). Children and parents: media use and attitudes report 2016. https://www.ofcom.org.uk/ data/assets/pdf_file/0034/93976/Children-Parents-Media-Use-Attitudes-Report-2016.pdf. Accessed 2 Apr 2019.

Ofcom (2019). Children's media lives: Year 5 findings. https://www.ofcom.org.uk/_data/assets/pdf_file/0029 /134795/Childrens-media-lives-Wave-5.pdf. Accessed 2 Apr 2019. 
Pillen, M., Beijaard, D., \& den Brok, P. (2013). Tension in beginning Teachers' professional identity development. Accompanying feelings and coping strategies. European Journal of Teacher Education, $36(2), 240-260$.

Plowman, L. (2015). Rethinking context: Digital technologies and children's everyday lives. Children's Geographies, 14(2), 190-202.

Robinson, M., \& Mackey, M. (2006). Assets in the classroom: Comfort and competence with media among teachers present and future. In J. Marsh \& E. Millard (Eds.), Popular literacies, childhood and schooling (pp. 200-220). London: Routledge.

Selwyn, N. (2003). Doint IT for the kids: re-examining children, computers and the information society. Media, Culture and Society, 25, 351.

Snyder, I. (2001). A new communication order: researching literacy practices in the network society. Language and Education, 15(2-3), 117-131.

Stephen, C., Stevenson, O., \& Adey, C. (2013). Young children engaging with technologies at home: the influence of family context. Journal of Early Childhood Research, 11(2), 149-164.

Wood, B., Rea, M., Plitnick, B., \& Figueiro, M. (2013). Light level and duration of exposure determine the impact of self-luminous tablets on melatonin suppression. Applied Ergonomics, 44(2), 237-240.

Publisher's note Springer Nature remains neutral with regard to jurisdictional claims in published maps and institutional affiliations.

In this paper, the term digital literacy is used to refer to any communicative or meaning making practice mediated by digital technology.

\title{
Affiliations
}

\section{Karen Daniels ${ }^{1} \cdot$ Kim Bower $^{1} \cdot$ Cathy Burnett ${ }^{1} \cdot$ Hugh Escott $^{1} \cdot$ Amanda Hatton $^{1} \cdot$ Ester Ehiyazaryan-White ${ }^{1} \cdot$ Jemma Monkhouse $^{1}$}

\author{
Kim Bower \\ dskb7@exchange.shu.ac.uk \\ Cathy Burnett \\ C.Burnett@shu.ac.uk \\ Hugh Escott \\ dshel@exchange.shu.ac.uk \\ Amanda Hatton \\ dsahb@exchange.shu.ac.uk \\ Ester Ehiyazaryan-White \\ dsee1@exchange.shu.ac.uk \\ Jemma Monkhouse \\ dsjm5@exchange.shu.ac.uk
}

1 Sheffield Hallam University, Sheffield S1 2ND, UK 